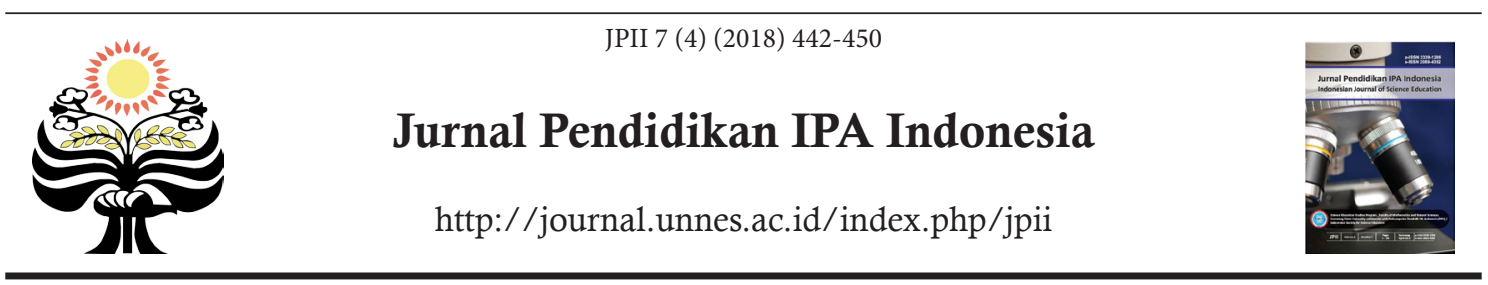

\title{
THE DEVELOPMENT OF INTEGRATED SCIENCE INSTRUCTIONAL MATERIALS TO IMPROVE STUDENTS' DIGITAL LITERACY IN SCIENTIFIC APPROACH
}

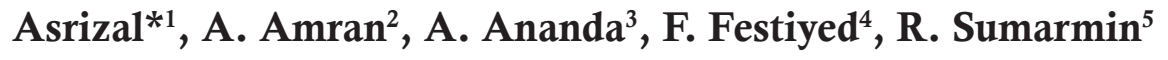 \\ ${ }^{1,4}$ Physics Department, Faculty of Mathematics and Science, Universitas Negeri Padang, Indonesia \\ ${ }^{2}$ Chemistry Department, Faculty of Mathematics and Science, Universitas Negeri Padang, Indonesia \\ ${ }^{3}$ Social Department, Faculty of Social Science, Universitas Negeri Padang, Indonesia \\ ${ }^{5}$ Biology Department, Faculty of Mathematics and Science, Universitas Negeri Padang, Indonesia
}

DOI: 10.15294/jpii.v7i4.13613

Accepted: July 20 $0^{\text {th }}$ 2018. Approved: December 10 $0^{\text {th }}, 2018$. Published: December $29^{\text {th }}, 2018$

\begin{abstract}
Integrated science and integration of literacy skills are relevant issues to be investigated in science education. This research aimed at determining the validity of integrated science materials and examining the practicality and effectivity of the use of integrated science materials in the scientific approach. The type of this research was research and development. The development of integrated science materials consists of seven stages, namely identifying potentials and problems, collecting information, designing a product, validating the product, revising product, doing limited testing, and revising product. Instruments for collecting data included validity assessment, practicality assessment, written test, and performance assessment. The data were analyzed by descriptive statistics and paired comparison test. Based on the data analysis, there were three results of this research. First, the validity of integrated science instructional materials classified as very high with an average value of 83.2. Second, the integrated science instructional materials were practical according to the science teachers and students with an average value of 86.11 and 89.66 respectively. Third, the integrated science instructional materials were effective in the scientific approach to improving the aspects of knowledge and digital literacy including scientific, functional, and visual literacy at $95 \%$ confidence level. These results indicated that employing integrated science instructional materials could overcome the problem of integrated science teaching and improve the digital literacy of students in terms of scientific, functional, and visual literacy. These digital literacy components are also useful for students to get success in their real future life.
\end{abstract}

(C) 2018 Science Education Study Program FMIPA UNNES Semarang

Keywords: integrated science, instructional material, digital literacy, scientific approach

\section{INTRODUCTION}

Learning in the 21st-century should have contexts, be linked to community life, be studentcentered, and be collaborative. Learning has context means that the content of learning materials must be associated with the real world. In this way, the material discussed in the school is close to the daily life of the students. In the learning

*Correspondence Address

E-mail: asrizal@fmipa.unp.ac.id process, students must be more involved actively to construct their competences. Competence construction in learning is done collaboratively. Hence, these four learning principles are the essence of 21st-century learning.

Integrated science learning is a proper way to apply the essence of 21 st-century learning. In integrated science learning, students are encouraged to connect the learning materials to realworld contexts. Students are involved actively in 
exploring the real-world contexts which are relevant to the learning materials, conducting the collaborative investigation, and communicating the investigation results. Thus, the learning process can be implemented holistically, authentically, meaningfully, and actively (Wiyanto \& Widiyatmoko, 2016).

Keeping in mind that the integration in learning is very important, The Indonesian Ministry of Education and Culture has established that science learning in the 2013 curriculum must be implemented in an integrated pattern. The content of the subjects comes from sub-discipline of science that is physics, biology, and chemistry. In other words, science learning should be integrated from those sub-discipline contents. The concept of science integration in the 2013 curriculum has been shown in both the core and basic competence. One basic competence has been integrating the science concepts of the sub-discipline of physics, biology, chemistry, and earth science and space (Pratiwi \& Muslim, 2016). In addition, in science development framework, scientific competence is connected to daily life, technology, and environment. Therefore, the 2013 curriculum has emphasized the importance of integration in science learning.

The Indonesian Ministry of Education and Culture also has promoted the school literacy program to improve students' literacy. Literacy is important for students to know, understand, and apply.

Therefore, in science learning, science teachers need to develop students' literacy so that they can obtain success either in their learning or real life. Integrated learning will gain knowledge and skills and make learning more meaningful to students as it is connected to the real world context. This integrated learning is more effective to improve the understanding and experience of students (Sunhaji, 2016). Integration in the curriculum could result in a greater intellectual curiosity, improve attitude, enhance problem-solving skills, and heighten achievement (Alghamdi, 2017). Integrated science learning allows students to get a direct experience in receiving, saving, and applying scientific concepts. Moreover, they are trained to discover the concepts by themselves holistically, meaningfully, authentically, and actively (Wiyanto \& Widiyatmoko, 2016).

However, the actual conditions in schools do not match with the expected conditions. There were at least three real conditions found in schools. First, junior high school science learning was conducted separately (Pursitasari et al., 2015). Ardianto \& Rubini (2017) also stated that teachers remain to teach science as a separate science into a sub-discipline of chemistry, physics, and biology. Science teachers generally find some difficulties in applying integrated science learning (Parmin et al., 2015). Second, the separation of integrated science textbooks into sub-disciplines of physics, biology, and chemistry (Asrizal et al., 2017). Third, Indonesian students' low literacy in reading, math, and science (OECD, 2013). These real conditions indicate that there is a problem to be investigated.

One of the alternative solutions to this problem is to develop integrated science instructional materials equipped with digital literacy. An important reason for this solution is that instructional materials can be used to facilitate teachers in implementing integrated science learning and students in studying science holistically and authentically. These instructional materials should be connected to the real-world contexts. On the other hand, the integration of digital literacy in learning is also important to encourage successful students in learning and in daily life.

Instructional materials are an important tool in a learning process of all subjects (Lyimo \& Too, 2017). Olayinka (2016) defined instructional materials as an essential and significant tool required for teaching and learning school subjects to promote efficiency and improve students' performance. Akpan et al. (2017) also explained that instructional materials as an object or device that aids teachers to present their lessons sequentially and logically to the students. On the other hand, Okobia (2011) stated that instructional materials as an object or device which helps teachers to make learning meaningful. Thus, instructional materials are required by both teachers for making effective learning and students for improving their performance in the learning process.

Instructional materials have some important roles in the learning process. The first role is to a more interesting, practical, realistic and meaningful learning (Olayinka, 2016; Saad, 2017; Zhang et al., 2013). Onyia (2013) said that instructional materials make simple learning, practical, effective and understandable to the students. The second role is to develop the knowledge, skills, attitudes, and values of students in the learning process (Saglam, 2011). The third role is to make learning easy, help memorize the things needed (Akpan et al., 2017). The fourth role is to let teachers and students to participate actively and effectively in learning. The fifth role is to enhance the learning outcomes, save time, increase students' interest, and facilitate retention of students' memory (Awolaju, 2016). Another role of 
instructional materials is to develop self-confidence, self-actualization, and motivation of students in learning (Olayinka, 2016; Saad, 2017).

There are several types of instructional materials which can be used in learning. Instructional materials can be divided into three major categories based on their sensory appeal, namely audio, visual and audio-visual (Akpan et al., 2017). Instructional materials include textbooks, workbooks, cassettes, CD-ROMs, videos, photocopied handouts, newspapers, etc., and they are used to impart knowledge (Hidayati, 2017). Instructional materials involve student's textbooks, teacher's guide, and reference books, maps and globes (Lyimo \& Too, 2017). Other types of teaching materials are textbooks, worksheets, workbooks, module, worktext, and manuals (Selga, 2013). An important thing, in this case, is instructional materials are a tool that can help teachers and students in the learning process and in making the learning more effective. In this research, instructional materials are integrated into science learning materials equipped with digital literacy.

Prior research results showed that the use of instructional materials provides a positive effect on students' academic achievement. The instructional materials adopted in secondary school learning have a positive effect on students' performance (Nwike \& Chaterine, 2013). Adebule $\&$ Ayoola (2015) stated that a significant difference existed between the performance of students taught with and without instructional materials. The research results of Olayinka (2016) also concluded that the students taught with instructional materials obtained excellent achievement scores compared to those taught without any materials. This explained that the use of instructional materials in learning has given a significant effect on the performance of students.

Integrated science instructional materials is an essential and meaningful tool necessarily applied aiming at promoting learning efficiency and improving students' performance. In this case, integration of science can be conducted by using the intra-disciplinary approach (Mubita \& Kalimaposo, 2016; Drake \& Savage, 2016; Bain et al., 2017). Furthermore, the integration of digital literacy into instructional materials is also needed to support a school literacy program. The digital literacy comprises basic, scientific, economic, technological, visual, information, and multicultural literacy (Turiman et al., 2012; Soh et al., 2012). On the other hand, Safeeq (2013) elucidated that digital literacy consists of functional, visual, scientific, technological, information, cultural, and global literacy. In learning, digital literacy requires students to make meaning in multimodal ways, using basic, scientific, technological, visual, gestural, spatial, information and multicultural literacy and global awareness (Jing, 2016; Fauzan et al., 2013).

The use of integrated science materials is considered important in the learning process. For this reason, researchers were attracted to develop the integrated science instructional materials equipped with digital literacy. The purposes of the research were to determine the validity of integrated science instructional materials according to experts' rational thinking and to determine its practicality and effectiveness when applied in the scientific approach.

\section{METHODS}

This was a developmental research intended to create a certain product and to test the effectiveness of the product. This research product was integrated science instructional materials equipped with digital literacy for three components, namely scientific, functional, and visual literacy.

The developmental model employed in this research referred to ten stages from Sugiyono. The referenced criteria were valid, practical, and effective in limited field testing. There were seven stages that have been done: (1) understanding potencies and problems; (2) collecting information; (3) designing the product; (4) validating; (5) revising; (6) implementing limited field testing; and (7) re-revising.

In general, there were three activity groups and seven stages in this research. The first activity group was to conduct a preliminary research. The preliminary research consisted of two stages including understanding potencies and problems and collecting information. The conducted activities included the analysis of curriculum analysis, integrated science textbooks, the students' literacy skills, and the students' learning outcomes. The results of the preliminary research were descriptions of integrated science in the 2013 curriculum, integration of teaching materials in integrated science textbooks, digital literacy, and students' competence.

The second activity group was designing, testing validity, and revising the product. Integrated science instructional materials were designed based on the guidance of the instructional materials development. The integrated science instructional materials consisted of learning guidance, core competence, and basic competence, 
teaching materials, supporting information, exercises, worksheets, evaluation and feedback from students. The components of the digital literacy integrated into the science instructional materials scientific, functional, and visual literacy. The product of instructional materials was validated by five experts of biology, physics, and chemistry.

The third activity group was to conduct a limited field testing and revising the product. The purpose of this limited field testing was to examine the practicality and effectiveness of the integrated science instructional materials. Based on the weaknesses and problems emerged in the limited field testing, a revision was carried out. The results of the activity were descriptions of the practicality and effectiveness of integrated science instructional materials in the scientific approach.

The employed instrument to examine the validity and practicality was questionnaire sheets which have been assessed and given some suggestions by three education experts. The indicators of the practicality covered usability, convenience, and attractiveness. On the other hand, the effectiveness indicators were the students' improvement of knowledge and literacy skills. The components of digital literacy were scientific, functional, and visual literacy. The instrument for measuring the students' knowledge was written test. This written test has been tested on other school students. The posttest had an average value of discrimination index, difficulty index, and reliability of $0.51,0.44$ and 0.69 respectively. Meanwhile, the instrument for determining the literacy skills components was the performance assessment sheet. This instrument has been designed from the indicators of scientific, functional and visual literacy. Thus, the instruments for collecting the research data were declared feasible.

The research data were analyzed through descriptive statistics and paired comparison test. The descriptive statistics analysis intended to describe more detailed information about the validity data from the experts, the practicality of the product according to the science teachers and students, also, knowledge and digital literacy of students. On the other hand, the paired comparison test was to examine the difference between the two groups of paired data after and before the treatment.

\section{RESULTS AND DISCUSSION}

The first research result was the validity of integrated science instructional materials which determined from two indicators, relevance and consistency. Relevance refers to content validity, while consistency relates to construction validity. Based on the validity assessment instrument from the experts, obtained the relevance and consistency value of integrated science instructional materials. There were six indicators which used to assess the validity of integrated science instructional materials, namely content feasibility, construction, integration of science materials, digital literacy, language, and graphics. The score of each validity assessment component is seen in Figure 1.

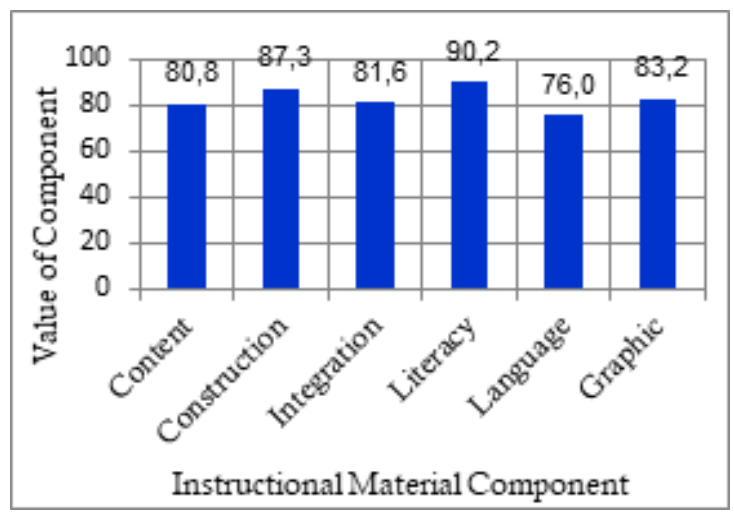

Figure 1. The Validity Scores of Integrated Science Instructional Materials

The average validity values of integrated science instructional materials varied from 76.0 to 90.2. Four components of the assessment criteria have been in a very valid category; those were construction, integration of instructional materials, digital literacy, and graphics. On the other hand, two components of instructional materials were in the valid category, those were content feasibility and language. The average validity score of the six assessment components was 83.2. This average value classified as a very valid category. Therefore, the average validity score was 83.2 and belonged to a very valid category.

On the basis of the validity test, the experts' suggestions could be grouped into three parts. The first suggestion was to show the relationship among sub-disciplines from physics, biology, and chemistry. To improve the integration within the sub-themes, the connected model was 
adopted since it model allows connection within concepts of the sub-disciplines. The second suggestion was to re-read the materials as there were some typographical errors. The third suggestion was to provide/create figures relevant to the learning materials since the initial figures were taken from internet sources.

The second research result was the practicality of the integrated science instructional materials equipped with digital literacy according to science teachers and students. There were three components assessed by the science teachers namely the usability, convenience, and attractiveness. The minimum value, mean value, and maximum score of each practicality component according to the science teachers are shown in Figure 2.

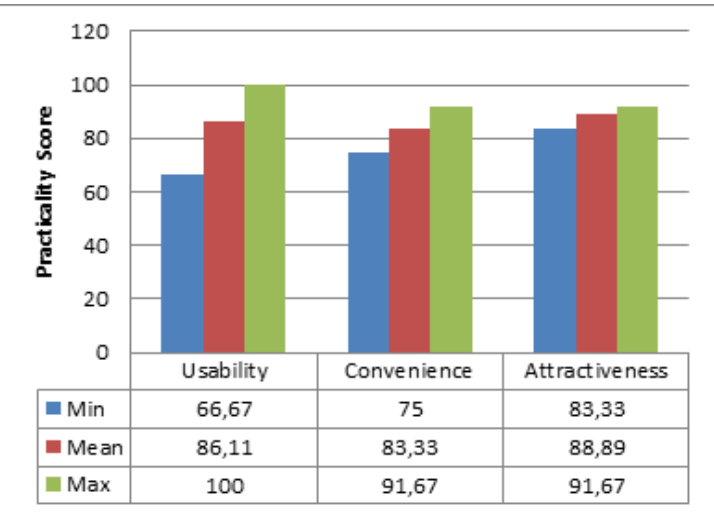

Figure 2. The Practicality Score of Instructional Materials According to Science Teachers

The usability aspect scores varied from 66.67 to 100 and the mean value was 81.11 . The convenience scores ranged from 75.00 to 91.67 and the average score was 83.33. On the other hand, the value of attractiveness varied from 81.33 to 91.67 and the average value was 88.89 . Therefore, the use of integrated science instructional materials integrated with digital literacy according to science teachers categorized as very practical.

Teachers thought that the integrated science instructional materials were useful as they assisted to accomplish the learning objectives, make science learning better, accelerate learning presentation, improve productivity, and control the time allotment. For the convenience aspect, the science teachers felt that the product eased to control learning materials, students' activities, memorize learning materials, understand science concepts, and improve learning results. On the ot- her hand, for the attractiveness aspect, the teachers agreed that the display, cover, and illustrations were interesting and fostered curiosity. Science teachers as users considered that integrated science instructional materials equipped digital literacy were useful, convenient, and appealing. Thus, the use of integrated science instructional materials equipped with digital literacy was practical in the scientific approach.

The practicality test of the integrated science instructional materials equipped with digital literacy was performed to the grade VIII students at one of Junior High Schools in Padang. The components assessed by the students were the same; usability, convenience, and attractiveness. The minimum, mean, and maximum values of each practicality component assessed by the students are displayed in Figure 3.

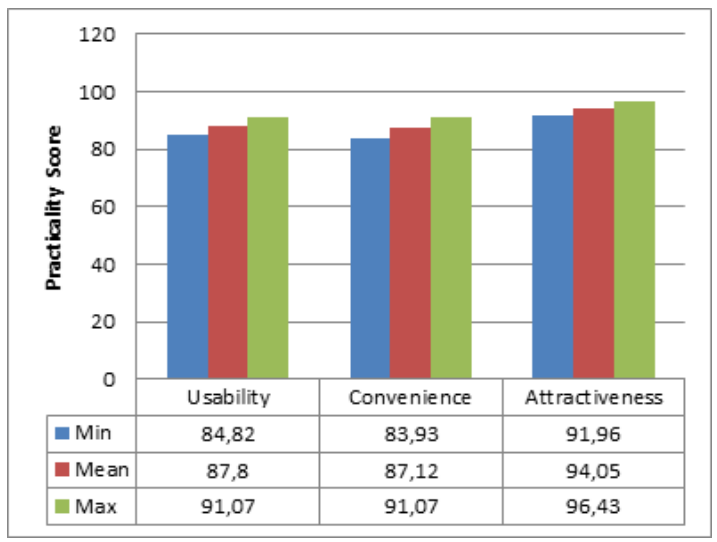

Figure 3. The Practicality Values of Instructional Materials According to Students

The usability aspect scores varied from 84.82 to 91.07 with an average value of 87.80 . Further, the convenience aspect score between 83.93 and 91.07 with an average value of 87.12. In addition, the attractiveness scores ranged from 91.96 to 96.43 with an average value of 94.05 . Overall, the three aspects' average value was 89.66. Thus, the use of integrated science instructional materials equipped with digital literacy according to students categorized as practical and very practical.

The third result was the effectiveness of the integrated science instructional materials on the aspects of students' knowledge and digital literacy. Therefore, a pre-test and post-test were carried out. The descriptive statistics score of pre-test, post-test, normality test, homogeneity, and paired comparison test can be observed in Table 1. 
Table 1. The Data Analysis of Students' Knowledge Aspect

\begin{tabular}{lcc}
\hline \multicolumn{1}{c}{ Statistical } & \multicolumn{2}{c}{ Scores } \\
\cline { 2 - 3 } Parameters & Pretest & Posttest \\
\hline Mean & 47.57 & 81.07 \\
Median & 52.00 & 80.00 \\
Mode & 52.00 & 76.00 \\
Standard deviation & 11.99 & 6.41 \\
Variance & 143.81 & 41.03 \\
Minimum & 16.00 & 72.00 \\
Maximum & 64.00 & 96.00 \\
Range & 48.00 & 24.00 \\
P-value of normal- & 0.038 & 0.013 \\
ity test & \multicolumn{2}{c}{0.002} \\
P-value of homoge- \\
neity test
\end{tabular}

Based on the data analysis results, the average value of the pre-test and post-test were respectively 47.57 and 81.07 . The post-test average value was higher than the pre-test. The $\mathrm{P}$ value of the pre-test and post-test in the normality test was smaller than the significance level $\alpha=0.05$. This means that the data of pre-test and post-test were not normally distributed. In the F test, the value of $\mathrm{P}$ was 0.002 or smaller than the value of significant level $\mathrm{a}=0.05$. These results indicated that both data of pre-test and post-test did not have the same variance.

The data of pretest and posttest did not own both normal distribution and same variance. Hence, the Wilcoxon signed rank test was used to analyze the data (Shan, 2014; Imam et al., 2014). The Wilcoxon test was used to analyze the differences from the observed results of two paired data. This test can be included in non-parametric statistics. The $\mathrm{Z}$ value for the 28 students was -4.63. At a significant level of 0.05 , the value of a half of significant level was 0.025 , then the area under the curve $F(z)=0.475$. The value of the $\mathrm{Z}$ table for this area under the curve $\mathrm{F}(\mathrm{Z})$ was 1.9. The value of the calculated $Z$ was outside the acceptance area of the Ho hypothesis. The hypothesis test results indicated that there was a significant difference in the knowledge aspect of students before and after they employed the integrated science instructional materials. Hence, the use of integrated science instructional materials was effective in the scientific approach to improve the knowledge aspect of grade VIII students at $95 \%$ confidence level.
An investigation was also done to determine the effectivity of the integrated science instructional materials on the students' digital literacy which consisted of scientific, functional, and visual literacy. In this case, functional literacy comprised writing and describing information while scientific literacy covered scientific concepts, scientific processes, and scientific contexts. Meanwhile, visual literacy consisted of visual interpretation and visual use. The scores of the statistical parameters on functional, scientific, and visual literacy before and after using the integrated science instructional materials are presented Table 2.

Table 2. The Scores of Statistical Parameters on Digital Literacy

\begin{tabular}{lcc}
\hline \multicolumn{1}{c}{ Statistical } & \multicolumn{2}{c}{ Scores } \\
\multicolumn{1}{c}{ Parameters } & Pretest & Posttest \\
\hline Mean & 47.57 & 81.07 \\
Median & 52.00 & 80.00 \\
Mode & 52.00 & 76.00 \\
Standard deviation & 11.99 & 6.41 \\
Variance & 143.81 & 41.03 \\
Minimum & 16.00 & 72.00 \\
Maximum & 64.00 & 96.00 \\
Range & 48.00 & 24.00 \\
$\begin{array}{l}\text { P-value of normal- } \\
\text { ity test }\end{array}$ & 0.038 & 0.013 \\
P-value of homo- \\
geneity test
\end{tabular}

Table 2 explains that the average value of scientific, functional, and visual literacy of the students before using the integrated science instructional material were respectively 54.58 , 49.27 and 47.44 . On the other hand, the average value of scientific, functional, and visual literacy of students after using the integrated science instructional materials were respectively 68.59 , 68,39 and 62.92 . The average values of the three aspects of digital literacy after using the integrated science materials equipped with digital literacy were higher. The $\mathrm{P}$ value for the students' literacy data before and after using the integrated science instructional materials indicated a normal distribution. Furthermore, the group of students' literacy data before and after using the integrated science instructional materials on the $\mathrm{F}$ test possessed the same variance. 
The data characteristics have met the statistical parameters. For this reason, a paired comparison test can be used to determine the difference of students' digital literacy after and before using the integrated science instructional materials. From the paired comparison test, t-values were obtained for functional, scientific, and visual literacy of $-18.43,-26.37$ and -16.94 respectively. On the other hand, the two-tailed test was obtained with a significant level of 0.05 and freedom degreed of 27, then the value of $t$ in the table was 2.05. The third t-value of the three digital literacies was out of the acceptance area of the null hypothesis.

The hypothesis test results indicated that there was a significant difference in functional, scientific, and visual literacy after and before employing the integrated science instructional materials in the scientific approach. In other words, the use of integrated science instructional materials equipped with digital literacy could give a meaningful impression in promoting students' digital literacy. The significant growth of digital literacy symbolized that the use of integrated science instructional materials was effective in the scientific approach particularly to augment the scientific, functional, and visual literacy of students at $95 \%$ confidence level.

Overall, the integrated science instructional materials equipped with digital literacy were declared valid in terms of content, construction, language, integration of teaching material, integration of digital literacy and graphics according to the experts. Moreover, the use of integrated science instructional materials in scientific approach was declared practical referring to the science teachers and the students. This elucidated that the teachers and students, as users, agreed that the integrated science instructional materials were useful, convenient, and appealing. In addition, the use of integrated science instructional materials equipped with digital literacy was effective in the scientific approach to improve the students' academic achievement. This result showed that the learning objectives can be achieved in terms of knowledge, attitude, and skills. The skill aspect of this research was described by scientific, functional, and visual literacy under the scope of digital literacy.

These research results aligned with the research findings done by Effiong \& Igiri (2015) which explained that the use of instructional materials gave a positive effect to the academic achievement of students. Similarly, the research results of Eze (2017) also showed that the use of instructional materials was effective in learning characterized by an improvement in academic achievement and retention of students. Furthermore, other research also proved that instructional materials supported the improvement of digital literacy. Yenni et al. (2017) explained that the use of science teaching materials could improve the content aspect and scientific literacy of students for the environmental pollution topic. In line with this, Ekantini \& Wilujeng (2018) found that science worksheet based on education for environmental sustainability was effective to increase scientific literacy. Thus, the research results were relevant to other studies which could support the skills which required in the 21-st century.

From the results that have been achieved, it can be stated that the use of the integrated science instructional materials equipped with digital literacy in the scientific approach was practical and effective to improve the students' knowledge and digital literacy. As an implication of the research results, science teachers may employ the materials as an alternative to learning resource in science learning. In addition, students can also use the integrated science instructional materials as one of the learning sources to construct knowledge and digital literacy in a science subject. Therefore, this research product was an alternative solution in applying integrated science learning and promoting the school literacy program.

\section{CONCLUSION}

The research concluded that the integrated science teaching materials owned generic criteria for a high-quality product in terms of validity, practicality, and effectiveness in the scientific approach. The validity was described into six components namely content, construction, integrated science teaching, integration of digital literacy, language, and graphics. These findings indicated that integrated science instructional materials have met the criteria of relevance and consistency. The use of integrated science instructional materials was practical in the scientific approach according to science teachers and students in the aspects of usability, convenience, and attractiveness. Moreover, the science teachers and students agreed that the use of instructional materials was useful, convenient, and appealing to support teaching processes. Besides, the use of integrated science instructional materials was effective in the scientific approach to improve aspects of knowledge and digital literacy including scientific, functional, and visual literacy. This means that the use of integrated science instructional material provided significant effects on knowledge and 
digital literacy. Therefore, science teachers could use the integrated science instructional materials as an alternative to improve knowledge and digital literacy of students.

\section{REFERENCES}

Adebule, S.O., Ayoola, O.O. (2015). Impact of Instructional Materials on Students' Academic Performance in Mathematics in Secondary Schools in Ekiti State, Nigeria. Research Journal of Educational Studies and Review, 2(1), 1-4.

Akpan, V. I., Okoli, A. C., Okpara, M., \& State, A. (2017). Effect of the Use of Instructional Materials on Academic Performance of Pupils in Ikwuano Abia State. International Journal of Trend in Research and Development, 4(1), 247-250.

Alghamdi, A. K. (2017). The Effects of an Integrated Curriculum on Student Achievement in Saudi Arabia. Eurasia Journal of Mathematics, Science and Technology Education, 13(9), 6079-6100.

Ardianto, D., \& Rubini, B. (2016). Comparison of Students'scientific Literacy in Integrated Science Learning through Model of Guided Discovery and Problem Based Learning. Jurnal Pendidikan IPA Indonesia, 5(1), 31-37.

Asrizal, Amran, A., Ananda, A., Festiyed, Yana, W.A. (2017). Effectiveness of Integrated Science Learning Materials of Waves in Life equipped with Digital Age Literacy on Grade VIII Students. Proceedings $1^{S T}$ Universitas Riau International Conference on Educational Sciences, 85-92

Awolaju, B. A. (2016). Instructional Materials as Correlates of Students' Academic Performance in Biology in Senior SecondarySchools in Osun State. International Journal of Information and Education Technology, 6(9), 705-709.

Bain, K., \& Siddique, M. N. A. (2017). Organization of Contents in Intended Junior Secondary Science Curriculum of Bangladesh: An Explorative Study. Science Education International, 28(2), 158-166.

Drake, S. M., \& Savage, M. J. (2016). Negotiating Accountability and Integrated Curriculum from a Global Perspective. International Journal of Learning, Teaching and Educational Research, 15(6), 127-144.

Effiong, O. E., \& Igiri, C. E. (2015). Impact of Instructional Materials in Teaching and Learning of Biology in Senior Secondary Schools in Yakurr LG A. International Letters of Social and Humanistic Sciences, 62, 27-33.

Ekantini, A., \& Wilujeng, I. (2018). The Developing of Student Science Worksheet Based on Education for Environmental Sustainable Development to Enhance Scientific Literacy. Universal Journal of Educational Research, 6(6), 1339-1347.

Eze, P. I. (2017). Effectiveness of Improvisation of Instructional Materials on Students' Academic Achievement and Retention in Christian Religious Studies (Crs). International Academic Jour- nal of Innovative Research, 4(1), 51-57.

Fauzan, A., Plomp, T., \& Gravemeijer, K. (2013). The Development of an Rme-Based Geometry Course for Indonesian Primary Schools. Educational Design Research-Part B: Illustrative Cases, 159-178.

Organisation for Economic Co-operation and Development. (2010). PISA 2009 Results: What Students Know and Can Do-Student Performance in Reading, Mathematics, and Science (Volume I). Paris: OECD Publishing.

Organisation for Economic Co-operation and Development. (2013). PISA 2012 results in focus: what 15-year-olds know and what they can do with what they know. Washington, DC: Author.

Imam, A., Mohammed, U., \& Moses Abanyam, C. (2014). On Consistency and Limitation of paired t-test, Sign and Wilcoxon Sign Rank Test. IOSR Journal of Mathematics, 10(1), 1-6.

Jing, L. I. U. (2016). Multiliteracies in College English Pedagogy. Sino-US English Teaching, 13(8), 601609.

Lyimo, N.S., \& Too, J. K. (2017). Perception of Teachers on Availability of Instructional Materials and Physical Facilities in Secondary Schools of Arusha District, Tanzania. International Journal of Educational Policy Research and Review. 4(5), 103-112.

Sephania, N., Too, J. K., \& Kipng'etich, K. J. (2017). Perception of Teachers on Availability of Instructional Materials and Physical Facilities in Secondary Schools of Arusha District.

Mubita, S. L., \& Kalimaposo, K. (2016). Factors Affecting Teaching and Learning of Home Economics in the Integrated Primary Curriculum : A Study of Selected Primary Schools in Lusaka province of Zambia. International Journal of Multidisciplinary Research and Development, 3(11), 9-16.

Nwike, M. C., \& Catherine, O. (2013). Effects of Use of Instructional Materials on Students Cognitive Achievement in Agricultural Science. Journal of Educational and Social Research, 3(5), 103-108.

Okobia, E. O. (2011). Availability and Teachers' Use of Instructional Materials and Resources in the Implementation of Social Studies in Junior Secondary Schools in Edo State, Nigeria. Review of European Studies, 3(2), 90-101.

Olayinka, A. R. B. (2016). Effects of Instructional Materials on Secondary Schools Students' Academic Achievement in Social Studies in Ekiti State, Nigeria. World Journal of Education, 6(1), 32-39.

Onyia, M. N. (2013). Instructional Materials and Design: Issues and Challenges. Academic Journal of Interdisciplinary Studies, 2(6), 153-158.

Pursitasari, I. D., Nuryanti, S., \& Rede, A. (2015). Promoting of Thematic-Based Integrated Science Learning on the Junior High School. Journal of Education and Practice, 6(20), 97-101. 
Pratiwi, T. R., \& Muslim, M. (2016). Using Integrated Type on Science Learning for Improving Junior High School Students'critical Thinking Skills. Jurnal Pendidikan Fisika Indonesia, 12(1), 54-64.

Saad, K. M. (2017). Effects of Instructional Materials on Cognitive Achievement of Secondary Schools Students in Economics in Gombe State, Nigeria. ATBU Journal of Science, Technology and Education, 5(2), 19-26.

Saglam, H. I. (2011). An Investigation on Teaching Materials Used in Social Studies Lesson. Turkish Online Journal of Educational Technology-TOJET, 10(1), 36-44.

Sajidan, Ashadi, Parmin \& Sutikno. (2015). Skill of Prospective Teacher in Integrating the Concept of Science with Local Wisdom Model. Indonesian Journal of Science Edu cation, 4(2), 120-126.

Selga, M. C. R. (2013). Instructional Materials Development: A Worktext in Science, Technology and Society. LCCB Development Education Journal of Multidisciplinary Research, 2(1), 1-1.

Shafeeq. C.P. (2013). Redefining Education in The World of ICTs. International Journal of English and Education, 2(1), 284-288.

Shan, G. (2014). New Nonparametric Rank-Based Tests for Paired Data. Open Journal of Statistics, 4(07), 495-503.

Soh, T. M. T., Osman, K., \& Arsad, N. M. (2012). M21CSI: A Validated 21st Century Skills Instrument for Secondary Science Students. Asian Social Science, 8(16), 38-44.
Sunhaji, S. (2013). The Impementation of Integrated Learning in The Islamic Religious Educationto Raise The Faith Devotion of The Students of State Seniour High Schools in Purwokerto. Dewantara, 1(1), 58-67.

Hidayati, N. (2017). Developing Teaching Materials of Natural Product Chemistry to Increase Student's Life Skills. Journal of Turkish Science Education (TUSED), 14(2), 27-41.

Turiman, P., Omar, J., Daud, A. M., \& Osman, K. (2012). Fostering the 21st Century Skills through Scientific Literacy and Science Process Skills. Procedia-Social and Behavioral Sciences, 59, 110-116.

Wiyanto \& Widiyatmoko, A. (2016). Preparation Model of Student Teacher Candidate in Developing Integrative Science Learning. Journal of Education and Human Development, 5(2), 169177.

Yenni, R., Hernani, \& Widodo, A. (2017, May). The Implementation of Integrated Science Teaching Materials based Socio-Scientific Issues to Improve Students Scientific Literacy for Environmental Pollution Theme. In AIP Conference Proceedings (Vol. 1848, No. 1, p. 060002). AIP Publishing.

Zhang, Q., Voogt, J., \& Akker, J. Van Den. (2013). A Professional Development Arrangement for Supporting Teachers' Enacting Inquiry-based Integrative Practical Activities in China. Educational Design Research - Part B: Illustrative Cases, 487-510. 